\title{
PANDANGAN DUNIA AKUTAGAWA DALAM KAPPA
}

\author{
Dyah Ekawati Eriolita \\ Sri Oemiati
}

\author{
(sri.oemiati@dsn.dinus.ac.id)
}

Universitas Dian Nuswantoro

\begin{abstract}
Akutagawa Ryuunosuke is a great author who lived during the Taishoo era (1912-1926). According to Akutagawa, every author must have a worldly instinct as an absolute impulse of wisdom. If an artist has lost his worldly instincts, it means he has ended himself as an artist. There are two ways left, being crazy or die. Worldly instincts are meant by human desire especially for food and sex. Before Akutagawa died, he had a chance to create a very famous literary work, Kappa (1927) which tell a situation between dreams and reality. Akutagawa indirectly wanted to convey what he felt in his life through one of his works, Kappa. In this study the author uses a genetic structuralism approach that emphasizes on the synchronic meaning. It is the meaning which concernes with events in a limited period. The aim of this study was to find out Akutagawa's world views on Japanese society in the Taishoo era, towards the Ie system, religion and women.
\end{abstract}

Kata kunci: world views, genetic structuralism, Kappa.

Zaman Taishoo (1912-1926) merupakan periode yang paling gemilang dalam sejarah novel Jepang. Novel-novel pada zaman itu lebih bervariasi dan rumit. Tema-temanya merupakan ekspresi kebebasan penulis yang menampilkan berbagai isu hangat, seperti masalah sosial pada saat itu. Salah satunya yakni novel Kappa karya Akutagawa Ryuunosuke.

Kappa menceritakan suatu keadaan di antara mimpi dan kenyataan. Kappa merupakan makhluk bersisik yang berukuran seperti anak kecil, wajahnya seperti harimau dan memiliki paruh yang runcing. Kappa hidup di sungai-sungai dan menyeret binatang-binatang dan anak-anak kecil yang ceroboh hingga mati. Lekukan di atas kepalanya penuh dengan air. Kappa juga dapat hidup di daratan.

Sedikit banyak Akutagawa menumpahkan pandangan hidup, kehidupan pribadinya ke dalam karya-karyanya. Dengan kata lain Akutagawa secara tidak langsung ingin menyampaikan apa yang dia rasakan dalam hidupnya dan hal itu dituliskan pada salah satu karyanya yaitu Kappa. Seperti halnya kebanyakan novel yang sedikit banyak menuliskan tentang kepribadian dan pengalaman pengarangnya, begitu juga Kappa tidak sepenuhnya terlepas dari kepribadian dan pengalaman penulisnya. Seperti dinyatakan Akutagawa sendiri dalam Kappa (1992:296), "Kappa lahir dari kemuakan saya dengan banyak hal - khususnya dengan diri saya sendiri”. 
Dyah Ekawati Eriolita dan Sri Oemiati, Pandangan Dunia Akutagawa dalam Kappa

Pandangan Akutagawa terhadap dunia yang disampaikannya dalam Kappa menjadi faktor ketertarikan penulis untuk menganalisis karya Akutagawa tersebut. Pandangan tersebut bukan sesuatu yang mutlak akan apa yang terjadi di zaman tertentu, melainkan sikap serta tanggapan Akutagawa secara utuh terhadap dunia yang ia hadapi. Pandangan semacam itu kemudian terwujud dalam sastra dan filsafat, yang oleh Akutagawa disampaikan melalui Kappa ini.

Adapun tujuan dari penelitian ini adalah untuk mengetahui pandangan dunia Akutagawa terhadap masyarakat Jepang pada zaman Taishoo yaitu terhadap sistem Ie, agama dan wanita.

\section{STRUKTURALISME GENETIK}

Strukturalisme genetik adalah suatu pendekatan terhadap karya sastra itu sendiri sebagai suatu keseluruhan dan sejarah sebagai proses kelahirannya.

Goldman, via Sapardi, (1984: 39) berpendapat:

Dalam kehidupan, manusia dan lingkungannya mempunyai hubungan yang bertentangan dan timbal balik di mana keduanya berakomodasi dan berasimilasi. Hubungan ini dituangkan oleh pengarang menjadi sebuah karya sastra yang merupakan respon pengarang terhadap peristiwa di sekitarnya. Dengan kata lain karya merupakan produk sejarah bukan fakta sejarah. Karya sastra tidak sepenuhnya berada di bawah faktor eksternal, seperti sejarah atau riwayat pengarang.

Dalam mengaplikasikan pendekatan struktural genetik, penulis hanya mengambil unsur-unsur tertentu, misalnya unsur intrinsik Kappa serta pandangan dunia Akutagawa terhadap masyarakat Jepang pada zaman Taishoo, yaitu terhadap sistem ie, agama dan prilaku wanita terhadap pria.

\section{UNSUR INTRINSIK KARYA SASTRA}

Pada penelitian ini tahap analisis dimulai dengan analisis struktural yaitu dengan cara menganalisis unsur intrinsik karya sastra yang mendukung penelitian. Unsur Intrinsik karya sastra penting dalam penelitian karya sastra, karena dengan memahami unsur intrinsik karya sastra peneliti karya sastra dapat lebih mudah memahami isi yang terkandung dalam sebuah karya sastra.

Menurut Goldman, pertama-tama seorang peneliti harus melihat teks sastra itu dari stuktur dalamnya (stuktur intrinsik) seperti alur, penokohan, sudut pandang, setting, dan lain-lain. Kemudian peneliti meneliti struktur luar (struktur eksternal).

Penulis hanya mengambil beberapa unsur intrinsik yang mendukung tercapainya tujuan penelitian ini sehingga dapat menjadi dasar pertimbangan analisis, yaitu: latar, tema serta tokoh dan penokohan.

\section{LATAR}

Latar bertujuan memudahkan penulis dalam menyesuaikan data dengan keadaan yang melatari karya sastra yang akan di teliti. Latar memiliki bermacam macam karakteristik antara lain: latar waktu, latar sosial, latar sejarah, dll.

Abrams via Nurgiyanto (1998:216): latar adalah lingkungan peristiwa yang merupakan dunia cerita tempat terjadinya peristiwa. Latar atau setting yang disebut juga sebagai landasan tumpu, menyarankan pada pengertian tempat, 
hubungan waktu, dan lingkungan sosial tempat terjadi nya peristiwa-peristiwa yang di ceritakan

Latar yang terungkap secara detail, dapat memberikan kemudahan pembaca untuk berimajinasi, memahami cerita, merasakan dan menilai kebenaran peristiwa yang tersaji dalam cerita.

\section{TEMA}

Tema merupakan inti cerita dan pokok pikiran yang mendasari cerita. Semua cerita dalam karya sastra tergantung pada tema, yang semuanya secara bersamasama melaksanakan atau mengungkapkan tema dalam cerita (Pradopo dalam Sangidu 2004: 128).

Berdasar pengertian tema dalam karya sastra tersebut, tema memegang peranan penting sebagai unsur intrinsik yang mengungkapkan inti dari sebuah karya sastra. Oleh karena itu, penulis mengambil tema sebagai salah satu dasar pertimbangan dalam analisis penelitian ini.

\section{TOKOH DAN PENOKOHAN}

Menurut Abrams (dalam Nurgiyantoro, 2000: 165) tokoh cerita adalah orang yang ditampilkan dalam karya, oleh pembaca ditafsirkan memiliki kualitas moral dan kecenderungan tertentu seperti yang diekspresikannya lewat ucapan dan tindakan .

Melalui unsur tokoh dan penokohan, penulis dapat memperoleh gambaran mengenai tokoh serta karakter masing-masing tokoh tersebut. Gambaran tersebut merupakan ekspresi tak langsung dari kepribadian maupun sikap pengarang terhadap suatu lingkungan yang diimajinasikan oleh pengarang.

\section{METODE PENELITIAN}

Penelitian ini menggunakan pendekatan deskriptif-kualitatif yang berarti data yang telah diperoleh berhubungan dengan kata-kata dan kalimat-kalimat. Oleh karena itu dalam penelitian ini penulis mengambil data yang berada dalam Kappa, serta sumber-sumber yang ada kaitannya dengan pendekatan strukturalisme genetik.

\section{PEMBAHASAN}

\section{UNSUR EKSTRINSIK}

\section{RIWAYAT HIDUP AKUTAGAWA RYUUNOSUKE}

Akutagawa Ryuunosuke (selanjutnya disebut Akutagawa) lahir di Irifunechoo, Tookyoo pada tanggal 1 Maret 1892 sebagai anak bungsu dari tiga bersaudara. Ia diberi nama Ryuunosuke karena lahir pada tahun dan jam Naga (sekitar jam 8 pagi). Ryuu dalam bahasa Jepang berarti naga. Ayahnya, Niihara Toshizoo adalah seorang pengusaha peternakan sapi perah di Irifunechoo, di daerah Shinjuku, dan ibunya bernama Fuku. Sembilan bulan setelah Akutagawa lahir,ibunya menjadi gila dan meninggal pada tahun 1902. Ketika Akutagawa lahir, ayahnya berusia 42 tahun dan ibunya berusia 33 tahun, usia sial menurut kepercayaan orang-orang 
Dyah Ekawati Eriolita dan Sri Oemiati, Pandangan Dunia Akutagawa dalam Kappa

Jepang. Untuk menghindari kemalangan yang akan menimpa, akhirnya Akutagawa seolah-olah dibuang dan dipelihara oleh teman ayahnya, Matsumura Senjiroo. Setelah itu Akutagawa diadopsi oleh kakak perempuan ibunya dan dirawat dengan penuh kasih sayang.

Sejak kecil Akutagawa sudah banyak mengenal karya klasik Jepang dan Cina, dan akrab dengan karya-karya Natsume Sooseki dan Mori Oogai. Saat SMU ia juga sudah membaca karya-karya penulis Eropa seperti Maupassant, Balzac, Tolstoy, Anatole Franc, Dostoyevski. Selain membaca karya sastra, Akutagawa juga sering melihat pameran dan menghadiri diskusi sastra, serta membaca buku di perpustakaan umum atau perpustakaan keliling.

Pada tahun 1913 ia masuk jurusan Sastra Inggris Universitas Tokyo. Bersama Kume Masao dan Kikuchi Kan, ia menghidupkan kembali majalah sastra yang sudah mati dan mulai menerbitkan karyanya di majalah tersebut. Debutnya dimulai dengan menerjemahkan karya France, Balthsar. Lulus dari universitas, Akutagawa mengajar bahasa Inggris di sekolah Teknik Kelautan di Yasuoka. Baru tiga tahun menjadi pengajar, ia berhenti karena ingin mencurahkan perhatian sepenuhnya pada kesusastraan.

Pada bulan Maret 1921 Akutagawa dikirim ke Cina selama empat bulan oleh surat kabar tersebut. Saat berada di Shanghai kesehatannya mulai memburuk dan semakin memburuk sejak kepulangannya dari Cina. Pada bulan Juni 1927 ketika berusia 35 tahun, Akutagawa meninggalkan sebuah catatan tentang bunuh dirinya, sebagai berikut :"Kita makhluk hidup, adalah mahluk jahat. Seperti orang lain, saya juga makhluk jahat. Tetapi ketika mengetahui bahwa saya telah kehilangan semua minat terhadap makanan dan seks, saya sadar bahwa saya secara bertahap sudah kehilangan vitalitas hewani saya. Saya yakin bahwa saya diizinkan oleh kehendak bebas saya untuk beralih ke dalam tidur abadi yang akan membawa saya pada kedamaian, atau malah kegembiraan. Tetapi itu tetap merupakan suatu pertanyaan kapan saya sebaiknya mengerahkan keberanian untuk bunuh diri. Tolong jangan publikasikan surat ini beberapa tahun setelah kematian saya. Kemungkinan bunuh diri saya bisa tampak seperti kematian dengan sebab-sebab alami."

\section{KARYA-KARYA AKUTAGAWA RYUUNOSUKE}

Walaupun Akutagawa hanya hidup selama 35 tahun, tapi ia benar-benar mengabdikan dirinya pada kesusastraan Jepang. Sebagai penganut paham intelektualisme, Akutagawa dengan tegas menolak naturalisme yang berjaya pada masa Meiji. Dalam mengarang karyanya, ia banyak mengambil latar belakang sejarah. Hal ini tidak terlepas dari kegemarannya membaca karya-karya klasik sejak kecil. Bukan untuk dijiplak, tapi hanya diambilnya sebagai sumber inspirasi. Seperti yang dikatakan oleh pengagumnya, sastrawan Hori Tatsuo, "pada akhirnya dia berakhir tanpa karya asli. Dalam setiap karya utamanya tetap hidup bayangan abad-abad sebelumnya."

Salah satu karya Akutagawa, yang sedikit banyak menceritakan kehidupan pribadinya adalah Kappa. Diterbitkan pada tahun 1927. Ada beberapa faktor yang mendorong Akutagawa menulis Kappa. Pertama, ketertarikannya pada amphibi 
imajiner ini memang sudah lama. Kedua, karya-karya besar novelis satir pujaannya seperti pinguin island oleh France, Erewhon oleh Butler, dan Gulliver's Travels oleh Swift, telah menumbuhkan inspirasinya untuk menghasilkan kappa. Dan terakhir, seperti yang di ungkapkan Akutagawa Ryuunosuke sebagai respon terhadap beberapa ulasan mengenai Kappa, yaitu :

"Kappa lahir dari perasaan kecewa saya terhadap segala hal, tetapi terutama terhadap diri saya sendiri. Semua berkomplot untuk membuat saya semakin ngeri terhadap diri sendiri." Para kritikus menilai bahwa karya tersebut adalah hasil dari kebrilianannya (Beongcheon 1972: 88).

\section{UNSUR INTRINSIK}

\section{LATAR}

Latar sosial dan budaya yang muncul hanya terbatas pada sistem ie, agama dan emansipasi wanita, karena Akutagawa ingin mengungkapkan sikap serta pandangannya terhadap ketiga hal tersebut melalui Kappa.

Struktur keluarga tradisional Jepang (ie) yang berlaku pada zaman Edo (16001868) masih terasa pada awal Taishoo. Konsep Ie berarti semua orang yang berdiam dalam sebuah rumah berpartisipasi dalam kehidupan sosial maupun ekonominya. Ie bersifat langgeng dari satu generasi ke generasi berikutnya tanpa bergantung kepada masa hidup kepala keluarga. Apabila kepala keluarga meninggal, maka kepala keluarga baru akan dipilih lewat pewarisan atau suksesi. Biasanya kepala keluarga baru ini adalah keturunan yang berdiam terus bersama orang tuanya setelah menikah. Konsep ie sangat menuntun kesinambungan keluarga yang harus selalu dijaga dan kepatuhan kepada orang tua. Pada zaman Taishoo, konsep Ie masih bertahan meskipun dengan kadar yang makin menipis.

Agama-agama selain Shintoo (kepercayaan awal orang Jepang) pada zaman Taishoo telah masuk di Jepang. Agama-agama tersebut antara lain Konfusianisme pada abad ke empat, Budha pada pertengahan abad ke 6, dan Nasrani yang mulai diperkenalkan sewaktu datangnya kapal Perry.

Meskipun demikian, tidak semua orang Jepang serius memikirkan tentang kehidupan spiritual atau agama, bahkan mereka lebih memikirkan kehidupan duniawi. Hal tersebut menjadi latar sosial kehidupan tokoh manusia dan tokoh Kappa yang Akutagawa gambarkan dalam novel Kappa.

Periode Taishoo adalah periode awal emansipasi wanita. Kedudukan wanita pada zaman Taishoo dalam keluarga semakin diakui. Dalam Kappa Akutagawa mengutarakan protes akibat perlakuan atas nama gender yang tidak adil dalam kabinet dengan menekan para pria melalui urusan bercinta.

\section{LATAR WAKTU}

Waktu yang dikisahkan dalam Kappa memang tidak merujuk pada suatu periode tertentu secara langsung, tetapi hanya sebatas waktu pagi, siang dan malam. Meskipun demikian, Akutagawa menyatakan bahwa Kappa merupakan ungkapan rasa muaknya terhadap apa yang terjadi di sekitarnya, serta apa yang ia alami akibat aturan sosial masyarakat yang berlaku selama ia hidup. Oleh karena itu, sedikit banyak latar cerita yang digambarkan pengarang adalah latar zaman 
Dyah Ekawati Eriolita dan Sri Oemiati, Pandangan Dunia Akutagawa dalam Kappa

Taishoo, karena Kappa diselesaikan pada 11 Februari 1927 (zaman Taishoo 19121926).

\section{LATAR TEMPAT}

Latar tempat dalam Kappa terbagi dua yaitu dunia manusia dan dunia Kappa.

Lokasi penceritaan pada bagian-bagian awal cerita, khususnya bagian pembukaan dan bagian satu, didominasi oleh nama-nama tempat di dunia manusia atau dunia nyata khususnya Jepang. Hal ini menunjukan kepada pembaca bahwa seakan-akan peristiwa penceritaan dalam Kappa merupakan suatu kenyataan atau kebenaran, dan hal ini memudahkan penulis untuk mengimajinasikan cerita.

Latar tempat dalam dunia Kappa hanya dideskripsikan sebagai suatu dunia yang memiliki kemiripan dengan dunia manusia khususnya di Jepang.

僕の両側に並んでいる町は少しも銀座通りと違いありません。やはり 毛生並み木のかげにいろいろの店が日除けを並べ、そのまた並み木に挟ま れた道を自動車が何台も走っているのです。

Boku no ryoogawa ni narande iru machi wa sukoshi mo ginzadoori to chigai arimasen. Yahari buseinanamiki no kage ni iroiro no mise ga hiyoke o narabe, sono mata namiki ni hasamareta michi o jidoosha ga nandai mo hashitte iru no desu. (Hal 69)

Jalan yang kami lalui mirip sekali dengan jalan Ginza di Tokyoo. Di balik deretan pohon di sepanjang jalan terdapat beragam toko dengan kamopi pelindung sinar matahari. Banyak mobil lalu lalang di jalan yang diapit deretan pepohonan itu.

\section{TEMA}

Masyarakat Kappa yang diceritakan pasien rumah sakit jiwa no. 23 merupakan cerminan masyarakat manusia yang digambarkan Akutagawa dengan menyakiti diri sendiri melalui kesakitan jiwanya. Ia merasa puas ketika menggambarkan masyarakat tersebut sebagai masyarakat yang memiliki cara pandang yang tidak masuk akal dan aturan yang buruk rupanya. Cara pandang serta aturan tersebut terwujud dalam sistem ie dan agama yang dimiliki masyarakat Jepang pada zaman Taishoo. Namun, ia tidak memandang sinis terhadap wanita pada zaman itu yang melakukan banyak hal yang berlawanan dengan kebiasaan wanita pada zaman sebelumnya. Ia justru mengagumi perjuangan wanita yang berusaha melakukan perubahan dalam masyarakat sosial, sekalipun dilakukan dengan cara-cara yang tidak lazim.

\section{TOKOH}

Tokoh dalam Kappa dibagi dua, yaitu tokoh manusia dan tokoh Kappa.

\section{Tokoh Manusia}

Setelah dilakukan tahap komparasi pembacaan pada novel asli dan terjemahan, tokoh manusia yang berperan utama dalam pembentukan cerita adalah "Aku". Selain itu, Aku merupakan sumber munculnya cerita. Tokoh Aku menganut paham sosialis. 
「ふん、君はこの国でも市民になる資格を持っている。。。。時に君 は社会主義者かね?」僕は勿論qua (これは河童の使う言葉では「然り」と いう意味を現すのです) と答えました。

"Fun, kimi wa kono kuni demo shimin ni naru shikaku o motte iru...toki ni kimi wa shakai shugisha ka ne?" Boku wa mochiron qua (kore wa kappa no tsukau kotoba de wa 'shikari' to iu imi o arawasu no desu) to kotaemashita. (hal 19)

Ya kau telah memiliki semua hal yang patut menjadikan dirimu sebagai masyarakat yang baik dari negeri kappa, seperti halnya di negerimu sendiri. Ah, ngomong-ngomong, kau seorang sosialis bukan? Tanpa keraguan aku menjawab "Qua" (ini adalah bahasa kappa yang berarti "ya")

"Aku" adalah seorang materialis dan tidak percaya akan hal-hal yang meyangkut kehidupan spiritual.

ぼく,僕はもちろんぶっしつしゅぎしや,勿論物質主義者ですから、まじ め,真面目にしゅうきょう,宗教をかんが,考えたことはいちど,一度もな かったのにちが,違いありません。

Boku wa mochiron busshitsu shugisha desu kara, majime ni shuukyoo o kangaeta koto wa ichido mo katta noni chigai arimasen. (Hal57)

Karena aku seorang yang materialis, maka tidak perlu lagi dijelaskan bahwa aku pernah berpikir serius masalah agama.

\section{Tokoh Kappa}

Kappa adalah mahluk gaib dalam Folklor Jepang yang hidup di sungai, kolam, danau dan laut. Tubuhnya diperkirakan seperti anak berumur 3 sampai 10 tahun. Ciri-ciri fisik yang khusus yaitu lekukan kecil di tengkorak bagian atas yang sering disebut cawan. Ketika lekukan itu berisi air, Kappa menjadi sangat kuat.

ではまたどういう動物かと言えば、頭に短い毛のあるのは勿論、手足 に水掻きのついていることも「水虎考略」のどに出ているのと著しい違い はありません。身長もざっと一メートルを越えるか越えぬくらいでしょう。 体重は医者のチャックによれば、二十ポンドから三十ポンドまで、一一稀 には五十何ポンドぐらいの大河童もいると言っていました。それから頭の まん中には楕円形の血があり、そのまた血は年齢により、だんだん固さを 加えるようです。現に年をとったバッグの血は若いチャックの血などとは 全然手ざわりも違うのです。しかし一番不思議なのは河童の皮膚の色のこ とでしょう。河童は我々人間のように一定の皮膚の色を持っていません。 何でもその周囲の色と同じ色に変わってしまう、一一たとえば草の中にい る時には草のように緑色に変わり、岩の上にいる時には岩のように灰色に 変わるのです。

De wa mata doo iu doobutsu ka to ieba, atama ni mijikai ke no aru no wa mochiron, teashi ni mizukaki no tsuiteiru koto mo 'suikokouryaku' nodo ni dete iru no to ichijirushii chigai wa arimasen. Shinchoo mo zatto ichi meetoru o koeru ka koenu kurai deshoo. Taijuu wa isha no chakku ni yoreba, nijuu pondo kara sanjuu ponto made, --- mare ni ha gojuu nan pondo gurai no ookappa mo iru to itte imashita. Sorekara atama no mannaka ni wa daenkei no chi ga ari, sono mata chi wa nenrei ni yori, dandan katasa o kuwaeru yoo desu. Gen ni toshi o totta baggu no chi wa wakai chakku no chi nado to wa zenzen tezawari mo chigau no 
Dyah Ekawati Eriolita dan Sri Oemiati, Pandangan Dunia Akutagawa dalam Kappa

desu. Shikashi ichiban fushigi na no wa kappa no hifu no iro no koto deshoo. Kappa wa wareware ningen no yoo ni ittei no hifu no iro o motte imasen. Nan de mo sono shuui no iro to onaji iro ni kawatte shimau, --- tatoeba kusa no naka ni iru toki ni ha kusa no youni midori ni kawari, iwa no ue ni iru toki ni wa iwa no yoo ni haiiro ni kawaru no desu. (hal 72)

Rambut di kepalanya sama, tangan dan kakinya berbulu. Panjang tubuhnya kira-kira 1 meter. Menurut Dr.Chakku, rata-rata berat badannya bervariasi antara dua puluh hingga tiga puluh pon. Ia juga mengatakan seseorang pernah melihat kappa tumbuh dengan bagus yang beratnya mungkin mencapai lima puluh sekian pon. Ciri-ciri yang membedakan kappa adalah cawan berbentuk oval yang terdapat di atas kepala. Seiring dengan bertambahnya usia, cawan oval ini perlahan lahan makin keras. Ada perbedaan antara cawan Chakku muda dengan cawan Baggu yang sudah tua. Namun aku berani mengatakan bahwa warna kulit kappa lah yang menjadi ciri yang paling membedakan. Warna kulit kappa tidak tetap seperti halnya kulit manusia, warna kulitnya akan berubah dan seperti akan berubah menjadi hijau. Ketika ia sedang berada di atas sebuah batu, warna kulitnya akan berubah menjadi abu-abu.

Kappa sangat popular di Jepang. Secara harfiah Kappa berarti "anak sungai". Nama lainnya yaitu Gawataroo, Kawako, Kawarakozoo. Di Iwami, Kappa juga disebut Enkoo, karena terlihat seperti monyet dan juga Suiko yang diambil dari buku Cina kuno. (Seiichi shiojiri, 1940: 12-23)

\section{Tokoh Chakku}

Pekerjaan Kappa Chakku adalah dokter

それはあと,後にし,知ったところによれば、あのはなめきん, 鼻目金をかけ たかっぱ,河童のいえ,家、—ちゃっく,チャックといういしゃ,医者のいえ， 家だったのです。

Sore wa ato ni shitta tokoro ni yoreba, ano hanamekin o kaketa kappa no ie, Chakku to iu isha no ie datta no desu.(Hal 72)

Kemudian aku tahu bahwa rumah itu milik kappa yang memiliki pince-nez tadi; Ia bernama dokter Chakku.

Umur dr.Chakku lebih muda dari pada Baggu

(うつつ,現にとし,年をとったばっぐ,バッグのさら,皿はわか,若いちゃっく， チャックのさら,血などとはぜんぜんて,全然手ざわりもちがうのです。)

Utsusu ni toshi o totta Baggu no sara wa wakai Chakku no sara nado to wa Zenzen tezawari mo chigau no desu.(hal 73)

Seiring dengan bertambahnya usia, cawan oval ini perlahan lahan semakin keras; ada perbedaan yang mencolok antara cawan Chakku muda dengan cawan Baggu yang sudah tua.

Kappa Chakku adalah seekor Kappa yang baik hati, mau memberi bantuan terutama pada "Aku" sebagai seorang yang sama sekali belum mengenal dunia Kappa.

ぼく,僕はいつもひぐ,日暮れがたになると、このへや,部屋にちやっく,チャ ックやばっぐ,バッグをむか,迎え、かっぱ,河童のことば,言葉をなら,習い ました。 
Boku wa itsumo higuregatta ni naru to, kono heya ni Chakku ya Baggu o mukae, Kappa no kotoba o naraimashita. (hal 71)

Di kamar inilah setiap malam Chakku, Baggu atau kappa kenalan ku yang lain mengajak ku mempelajari bahasa kappa.

Kappa Chakku jugalah yang membantuku disaat Baggu mulai membuatku takut.

ちょうどそこへかお,顔をだ,出したのはさいわ,幸いにもいしゃ,医者のちゃ っく,チャックです。「こら、ばっぐ,バッグ、なに,何をしているのだ?」 ちやっく,チャックははなめきん, 鼻目金をかけたまま、こういうばっぐを にら,睨みつけました。

Choodo soko e kao o dashita no wa aiwai ni mo isha no Chakku desu. "Kora, Baggu, nani o shite iru no da? " Chakku wa hanamekin o kaketa mama, koo iu baggu o niramitsukemashita. (hal 72)

Dokter Chakku muncul dari arah pintu yang terbuka. Baggu tidak mempunyai pilihan lain . ' tenang, Baggu! Apa yang kau lakukan? Chakku membelalak kearah baggu melalui pince-nez nya.

Kappa Chakku adalah seekor Kappa materialis

もっともちゃっく,チャックはぶっしつしゅぎしゃ,物質主義者ですから、

しうし,死後ろのせいめい,生命などをしん,信じていません。

Motto mo Chakku wa bushitsu shugisha desu kara, shiushiro no seimei nado o shinjite imasen.

Tentu saja, sebagai seorang yang materialis, Chakku tidak percaya begitu saja dengan hal semacam itu.

\section{Tokoh Baggu}

Kappa Baggu adalah seekor kappa pencari ikan

(またみっか,三日にいちど,一度くらいはぼく,僕のさいしょ,最初にみ,見か

けたかっぱ,河童、——ばっぐ,バッグというぎょふ,漁夫もたず,尋ねてきま

した。)

Mata mikka ni ichido kurai wa boku no saishoo ni mikaketa kappa, Baggu to iu gyofu mo tasunete kimashita. (hal 70)

Baggu, kappa yang aku temui pertama kali, yakni kappa pencari ikan, menjengukku setiap tiga hari sekali.

Kappa Baggu adalah Kappa yang baik hati yang selalu memberikan bantuan kepada tokoh "Aku"

しかしさいしょ,最初のはんつき,半月ほどのあいだ,間にいちばんぼく, 一番僕とした,親しくしたのはやはりあのばっぐ,バッグというりょう すえ,漁末だったのです。)

Shikashi saisho no hantsuki hodo no aida ni ichiban boku to shitashiku shita no wa yahari ano Baggu to iu ryoosue datta no desu. (hal71)

Namun dalam dua minggu pertama, Baggu si pencari ikanlah yang menjadi temanku.

Salah satu Kappa yang menaruh perhatian padaku. Baggu menolong ku mencari jalan keluar kembali kedunia manusia dan Setelah kembali ke dunia manusia, Baggulah yang pertama kali menjenguk "Aku" 
Dyah Ekawati Eriolita dan Sri Oemiati, Pandangan Dunia Akutagawa dalam Kappa

そのうちにあのばっぐ,バッグというりょうすえ,漁末のかっぱ,河童のはな し,話には、なん,何でもこのくに,国のまち,街はずれにあるとし,年をとっ たかっぱ,河童がいっぴき,一匹、ほん, 本をよ,読んだり、ふえ,笛をふ,吹い たり、しず,静かにくれ, 暮らしているということです。ぼく,僕はこのかっ ぱ,河童に尋ねてみれば、あるいはこのくに, 国をに, 逃げだ,出すと, 途もわ かりはしないかとおも,思いましたから、さっそくまち,早速街はずれへで, 出かけてい,行きました。

Sono uchi ni ano Baggu to iu ryoosue no kappa no hanashi wa, nan demo kono kuni no machi hazure ni aru toshi o totta kappa ga ippiki, hon o yondari, fue o fuitari, shizuka ni kurerashite iru to iu koto desu. Boku wa kono kappa ni nete mireba, arui wa kono kuni o nigedasu to mo wakari wa shinai to omoimashita kara, sassoku machi hazure e dekakete ikimashita. (hal 135)

Sementara itu, si pencari ikan Baggu memberitahukan bahwa di suatu tempat di daerah pinggiran kota hidup seekor kappa tua yang mengisi hari-harinya dengan membaca buku dan meniup seruling. Segera aku kesana dan berharap ia dapat memberi tahu jalan untuk keluar dari negeri kappa.

「おい、ばっぐ,バッグ、どうしてき,来た?」

「へい、おみま,見舞いにのぼ,上ったのです。なん,何でもごびょうき,御病 気だとかいうことですから」)

"Oi, Baggu, dooshite kita?" "Hei, omimai ni nobotta no desu. nan de mo go byooki da toka iu koto desu kara." (hal 141)

'Hai! Baggu! Untuk apa kau datang kemari?'

'Oh, aku datang kesini untuk mengunjungimu. Ada kabar bahwa kau sakit'

\section{Tokoh Rappu}

Rappu adalah Kappa pelajar yang banyak memberi bantuan pada tokoh "Aku" selama di dunia Kappa.

するとそこへ馸けこんで来たのはあのラップという学生です。

Suru to soko e kakekonde kita no wa ano Rappu to iu gakkusei desu.

Tiba-tiba pintu terbuka da sosok dengan sempoyongan masuk dan jatuh ke lantai, dia adalah Tokku si murid.

(ぼく,僕はこのらつぷ,ラップというかっぱ,河童にばっぐ,バッグにもおと， 劣らぬせわ,世話になりました。が、そのなか, 中でもわす,忘れられないの はとっく,トックというかっぱ,河童にしょうかい,紹介されたことです)

Boku wa kono Rappu to iu kappa ni Baggu ni mo otoranu sewa ni narimashita. Ga, sono naka de mo wasurerarenai no wa Tokku to iu kappa ni shookai sareta koto desu. (hal 78)

Ternyata Rappu sangat perhatian padaku sebagaimana halnya Baggu. Keduanya telah melakukan banyak hal untuk membantuku. Rappu bahkan memperkenalkanku dengan kappa lain bernama Tokku. Inilah yang menjadi salah satu kebaikan hati Rappu yang tak terlupakan.

Kappa Rappu adalah seekor kappa yang tidak terlalu serius memikirkan agama. Ketidakyakinannya terhadap agama dan Tuhan ditunjukannya melalui sikap yang malas mengkaji kitab suci dan beribadah. 
(それかららつぷ,ラップはとうとう,滔々とぼく,僕のことをはな,話しまし た。どうもまたしれはこのだいじいん,大寺院へらっぷ,ラップがめった, 滅 多にこ,来ないことのべんかい,并解にもなっていたらしいのです。） Sore kara Rappu wa tootoo to boku no koto o hanashimashita. Doomo mata shire wa kono daijin e Rappu ga metta ni konai koto no benkai ni mo natte ita rashii no desu. (hal 122)

Rappu lalu banyak bicara tentang aku dengan kata-kata yang lancar dan jelas. Tindakan ini lebih sekedar bahwa ia merasa bersalah karena telah lama tidak menampakan diri ke Kuil Besar ini

『。。○らつぷ,ラップさん、あなたはこのかたにわれわれ,我々のせいし よ,聖書くをごらん,御覧にい,入れましたか?」「,?』『いえ。。。じつ, 実はわたししろみ,白身もほとんじよ,読んだことはないのです」,』らっぷ, ラップはあたま,頭のさら,血をか,掻きながら、しょうじき,正直にこうへん じ,返事をしました。

"Rappu san, anata wa kono kata ni wareware no seishoku o goran ni iremashitaka?" "Ie...jitsu wa watashi shiromi mo hotondo yonda koto wa nai no desu” Rappu wa atama no sara o kakinagara, shoojiki ni koo henji o shimashita. (hal 126)

'Rappu ,apakah kau pernah memperlihatkan pada tuan ini tentang kitab-kitab suci kita?'

'Belum. Sejujurnya, saya sendiri belum pernah membaca kitab-kitab itu'

Rappu menggaruk-garuk cawan yang ada diatas kepalanya saat ia mengakui hal ini.

Rappu juga seekor Kappa yang pemurung dan tidak percaya diri. Ini dinyatakannya pada saat dia mengadu kepada "Aku" mengenai masalah tersebut.

じさい,字際またらっぷ,ラップはみぎ,右のあし,脚のうえ,上へひだり,左の あし,脚をのせたままくさ,腐ったくちばし,觜もみえないほど、ほんぎやり ゆか,床のうえ,上ばかりみていたのです。「らつぷ,ラップくん, 君，どう したねとい,言えば」「いや、なに,何、つまらないことなのですよ らっぷ,ラップはやっとあたま,頭をあ, 挙げ、かな, 悲しいはなごえ, 鼻声を だ,出しました。

Jisai mata Rappu wa migi no ashi no ue e hidari no o noseta mama, kusatta kuchibashi mo mienai hodo, hongyari yuka no ue bakari mite ita no desu. "Rappu kun, dooshita ne to ieba" "Iya, nani, tsumaranai koto nado desu yo" Rappu wa yatto atama o age, kanashii hanagoe o shimashita. (hal 17)

Kaki kirinya ditumpangkan di atas kaki kanan, matanya menatap kosong dan muram kelantai. Kepalanya tertunduk lemah hingga paruhnya yang membusuk tidak tampak.

'ada apa dengan dirimu? Kau tampak sangat sedih'

Rappu tidak menjawab.

'Rappu! Ayolah Aku bertanya ada masalah apa.'

'Oh! Apa Tadi? Oh ini tidak begitu serius benar'

Untuk waktu lama, akhirnya Rappu mengangkat kepala dan mulai bercerita dengan nada sedih. 
Dyah Ekawati Eriolita dan Sri Oemiati, Pandangan Dunia Akutagawa dalam Kappa

\section{Tokoh Tokku}

Kappa Tokku adalah Seekor Kappa penyair

(とつく,トックかっぱなかま,河童仲間のしじん,詩人です。しじん,詩人が かみ,髪をなが,長くしていることはわれわれにんげん,我々人間とか,変わり ません。

Tokku kappa nakama no shijin desu. Shijin ga kami o nagakushite iru koto wa wareware ningen to kawarimasen. (Hal 78)

Tokku adalah salah satu penyair di lingkungan seniman kappa. Ia memanjangkan rambut sebagaimana para penyair Jepang.

Tokku menyatakan bahwa dia adalah super kappa

「ぼく,僕か?ぼく,僕はちょうじん,超人（ちょくやく,直訳すればちょ うかっぱ,超河童です) だ」

"Boku ka? Boku wa choojin (chokuyaku sureba chookappa desu) da" (hal 80) 'Aku? Tidak, aku seorang superman. '(sebenarnya, kata yang ia gunakan secara harfiah adalah super-kappa)'

Dia juga mempunyai banyak teman sesama seniman, dan selalu berkumpul di klub super Kappa

ちょうじんくらぶ,超人俱楽部にあつ,集まってく,来るのはしじん,詩人、し ょうせつか,小説家、ぎきょくか, 戯曲家、ひひょうか, 批評家、がか, 画家、 おんがくか, 音楽家、ちょうこくか, 彫刻家、げいじゅつじょう,芸術上のし ろうとなど,素人等です。)

Choojin kurabu ni atsumatte kuru no wa shijin, shoosetsuka, gikyokuka, hihyooka, gaka, ongakuka, chookokuka, geijutsujoo no shirouto nado desu. (hal 80)

Hampir semua anggota klub super kappa tampaknya dalam hal tertentu berhubungan dengan seni, di antara mereka adalah penyair, novelis, penulis drama, kritikus, pelukis, pencipta lagu, pematung, dan banyak seniman amatir. Kappa Tokku juga seekor Kappa yang mengakhiri hidupnya dengan cara bunuh diri, sebelum bunuh diri dia mengalami paranoid, halusinasi, dan mengalami kesulitan tidur

「。。ぼく,僕もこのに,二、さんしゅうかん,三週間はねむ,眠られないの によわ,弱っているのだ」「どうだね、ぼく,僕らといっしょにさんぽ,散歩 をしては」「いや、きょうはやめにしよう。おや!」とっく,トックはこ

うさけ,叫ぶかはや,早いか、しつかりぼく,僕のうで,腕をつか,摑みました。 しかもいつかからだじゅう,体中にれいかん,冷汗をなが,流しているのです。 「どうしたのだ！」「どうしたのです?」「なに,何、あのじじうしや,自 動車のまど,空のなか,中からみどり,緑いろの猿が一匹首を出したように見 えたのだよ」

“...Boku mo kono ni, sanshuukan wa nemurarenai no ni yowatte iru no da” "Doo da ne, bokura to issho ni sanpo o shite wa" "Iya, kyoo wa yame ni shiyoo. Oya!" Tokku wa koo sakebu ka hayai ka, shikkari boku no ude o tsukamimashita. Shikamo itsu ka karadajuu ni reikan o nakashite iru no desu. "Dooshita no da!" "Dooshita no desu?" "Nani, ano jidoosha no mado no naka kara midori iro no saru ga ippiki kubi o dashita yoo ni mieta no da yo. (hal 105-106) 
'Aku juga, setidaknya untuk dua atau tiga minggu terakhir ini, aku tidak bisa tidur dan ini membuatku sangat lemah.'

'Oh, kasihan betul, bagaimana kalau ikut kami jalan-jalan?'

'Tidak, terimakasih. Aku pikir aku harus istirahat hari ini. Oh Tuhan!'

Tokku berteriak ketakutan dan memegang tangan ku erat-erat. Tiba-tiba, tubuhnya menggigil kedinginan.

'Apa yang terjadi?', aku dan Rappu bertanya serentak.

'Aku kira aku melihat seekor kera hijau menjulurkan lehernya dari dalam jendela mobil di sana'

Kappa Tokku juga dikenal sebagai Kappa yang tidak mempunyai sahabat

しんゆう,親友?とっく,トックはいつもこどく,孤独だったのです。。

しやばかい, 娑婆界をへだ,隔つるたに, 谷へ、。。。ただとっく,トックはふ こう,不幸にも、。。。))

Shinyuu? Tokku wa itsumo kodoku data no desu.... shabakai o hedatsuru tani e... tada Tokku wa fukoo ni mo,..... (hal 118)

'Teman? Ah!.... Tapi Tokku selalu seperti serigala yang kesepian...'

Kappa Tokku adalah seekor kappa yang punya sifat tidak peduli dengan sistem keluarga.

とっく,トックはよくかっぱ,河童のせいかつ,生活だのかっぱ,河童のげいじ ゆつ,芸術だののはなし,話をしました。とっく,トックのしん,信ずるところ によ,寄れば、あた,当りまえ,前のかっぱ,河童のせいかつ,生活ぐらい、ば か, 莫迦げているものはありません。おやこふうふきょうだい, 親子夫婦兄 弟などとい,言うのはことごとくたが,互いにくる, 苦しめあ,合うことをゆい いつ,唯一のたの,楽しみにしてく,暮らしているのです。ことにかぞくせい ど,家族制度というものはばか,莫迦 げ,ゲてい,手居るいじょう,以上にもば か,莫迦げているのです。

Tokku wa yoku kappa no seikatsu da no kappa no geijutsu da no no hanashi o shimashita. Tokku no shinzuru tokoro ni yoreba, atarimae no kappa no seikatsu gurai, bakagete iru mono wa arimasen. Oyako fuufu kyoodai nado to iu no wa kotogotoku tagai ni kurushimeau koto o yuiitsu no tanoshimi ni shite kurashite iru no desu. Koto ni kazoku seido to iu mono wa bakagete iru ijoo ni mo bakagete iru no desu. (hal 79)

Tokku selalu berbicara tentang kehidupan dan seni kappa. Dasar keyakinannya adalah bahwa tidak ada satupun di dunia ini yang benar-benar absurb seperti kehidupan para kappa di jalanan. Menurutnya, para orang tua dan anak-anak, suami dan istri, kakak dan adik, semuanya hanya melewatkan hari-harinya sesuka hati mereka, sehingga membuat hidup memberatkan satu sama lain.

\section{Tokoh Maggu}

Maggu adalah filosof di dunia kappa. Dia sudah menerbitkan buku yang berisi renungan-renungan dalam hidup

このこん,近)ころ,頃まっぐ,マッグのか,書いた「，『あほう,阿呆のこと ば,言葉」,』というほん,本を見舞え。 
Dyah Ekawati Eriolita dan Sri Oemiati, Pandangan Dunia Akutagawa dalam Kappa

Kono chikagoro maggu no kaita "ahoo no kotoba" to iu hon o mitamae. (hal104)

Akhir-akhir ini, lihatlah buku tulisan Maggu, yaitu "Kata-kata Tolol" .

Maggu adalah Kappa yang kurang suka bergaul dan jarang keluar rumah

まっぐ,マッグだけはあまりおうらい,往来へかお,顔をだ,出さずにいえ,家 にばかりいるためです。)

Maggu dake wa amari oorai e kao o dasazu ni ie ni bakari iru tame desu. (hal 84)

Maggu tidak terlalu suka bergaul, dia hanya menghabiskan waktunya di rumah saja.

Mungkin karena itu juga dia tidak pernah dikejar-kejar kappa betina seperti kappa jantan lainnya. Tetapi meskipun begitu, dia hanyalah seekor kappa biasa yang juga memendam nafsu birahinya

「しかしわたしもどうかすると、あのおそ, 恐ろしいめす,此のかっぱ,河 童にお,追いかけられたいき,気もおこ,起るのですよ」

"Shikashi watashi mo doo ka suru to, ano osoroshii mesu no kappa ni oikakeraretai ki mo okoru no desu yo." ( hal85)

"Tidakkah kau menyadari bahwa selama ini aku merasa suatu hasrat yang membara untuk ditangkap oleh salah satu kappa betina yang menjijikan itu?'

Kappa Maggu juga seekor Kappa yang percaya bahwa ada kekuatan lain diluar Kappa. Ini ditunjukannya pada salah satu peristiwa yang menggugah hati nurani maggu, yaitu kematian Tokku.

マッグだけはトックの死骸を眺めたまま、ぼんやり何か考えています。僕 はマックの型を吅き、『何を考えているのです?』と尋ねました。『河童 の生活というものを祀』『河童の生活がどうなるのです?』『我々河童は 何といっても、河童の生活を完うするためには、。。。』マックは多少羞 しそうにこう小声でつけ加えました。『とにかく我々河童以外の何にもの かのカを信ずることですね』

Maggu dake wa tokku no shigai o nagameta mama, bonyari nani ka kangaete imasu. Boku wa makku no kata o tataki, "nani o kangaete iru no desu?" to tazunemashita. "Kappa no seikatsu to iu mono o ne" "Kappa no seikatsu ga doo naru no desu?" "Wareware kappa wa nan to itte mo, kappa no seikatsu o kan'u suru tame ni wa..." Makku wa tashoo shuushisoo ni koo kogoe de tsukekuwaemashita. "Tonikaku wareware kappa igai no nani ni mo no ka no chikara o shinzuru koto desu ne." (Hal 121)

Maggu masih saja merenungkan sesuatu dengan mata tertuju pada mayat Tokku. Aku menepuk bahu Maggu dan bertanya:

"Apa yang sedang kau pikirkan?"

"Oh kehidupan kappa ini"

"Kehidupan kappa?"

"Yah, kau tahu. Ketika semua telah berakhir untuk memenuhi hidupnya, kappa itu."

...Kemudian, ia menambahkan dengan wajah malu-malu dan nada yang lemah.., ia percaya atau yakin pada suatu kekuatan yang benar-benar ada di luar kappa. 


\section{Tokoh Kurabakku}

Kappa Kurabakku adalah musikus yang juga anggota super Kappa くらばっく,クラバックはとっく,トックがぞく,属しているちょうじんくら ぶ,超人俱楽部のかいいん,会員ですか、)

Kurabakku wa Tokku ga zokushite iru choojin kurabu no kaiin desu ka (hal.86)

Kurabakku adalah salah satu anggota klub super kappa Tokku.

Kappa musikus yang suka bertingkah laku ekstrim.

するとくらばっく,クラバックはた,立ちのぼ,上るがはや,早いか、たな ぐら,タナグラのにんぎょう,人形をひっつか, 摑み、いきなりのうえ,上にた た,吅きつけました。「だれ,誰がけんそんいえ,謙遜家をき,気どるものか? だいいちきみ,第一君たちにき,気どってみ,見せるくらいならば、ひひょう か,批評家たちのまえ,前にき,気どってみ,見せている。ぼく,僕は__くら ばっく,クラバックはてん,天才だ。その点ではロックを恐れていない」） Suru to Kurabakku wa tachinoboru ga hayai ka, tanagura no ningyoo o hittsukami, ikinari no ue ni tatakitsukemashita. "Dare ga kensonka o kidoru mono ka? Daiichi kimitachi ni kidotte miseru kurai naraba, hihyookatachi no mae ni kidotte misete iru. Boku wa Kurabakku wa tennsai da. Sono ten de wa Rokku o ..." (Hal 103)

Seketika itu, Kurabakku melompat dari tempat duduknya, mengambil boneka Tanagra, dan membantingnya dengan keras ke lantai. Rappu tampak sangat ketakutan, sampai ia berteriak dan hampir melarikan diri. Namun, Kurabakku memberi isyarat pada kami (aku dan Rappu) agar tidak takut sambil berkata 'Hem! Itu karena kau tidak punya telinga seperti halnya kappa-kappa yang lain. Jika saja hal yang sebenarnya ku katakan, aku khawatir atas Rokku, aku menghormatinya.'

\section{Tokoh Geeru}

Kappa Geeru adalah seekor Kappa direktur perusahaan gelas di negeri Kappa ぼく,僕はがらすがいしや,硝子会社のしゃちょう, 社長のげえる,ゲエルふ しぎ,不思議にもこうい,好意をも,持っていました。げえる,ゲエルはしほん かちゅう, 資本家中のしほんか, 資本家です。おそ, 恐らくはこのくに, 国のか つぱ,河童のなか, 中でも、げえる,ゲエルほどおお,大きいはら,腹をしたか つぱいっぴき,河童一匹おいなかったのに違いありません。しかしれいえ だ,荔枝にに, 似たさいくん, 細君やきゅうり, 胡瓜にに, 似たこども, 子供をさ ゆう,左右にしながら、あんらくいす, 安楽椅子にすわ,坐っているところは ほとんど幸福そのものです。）

Boku wa garasu kaisha no shachoo no Geeru fushigi ni mo kooi o motte imashita. Geeru wa shihonkachuu no shihonka desu. Osoraku wa kono kuni no kappa no naka de mo, Geeru hodo ookii hara o shita kappa ippiki oinakatta noni chigai arimasen. Shikashi reieda ni nita saikun ya kyuuri ni nita kodomo o sayuи ni shinagara, anraku isu ni suwatte iru tokoro wa hotondo koofuku sono mono desu. (Hal 89) 
Dyah Ekawati Eriolita dan Sri Oemiati, Pandangan Dunia Akutagawa dalam Kappa

Seumur hidup aku tidak akan bisa menjelaskan dengan kata-kata, namun aku tahu bahwa aku suka bersahabat dengan Geeru, direktur perusahaan gelas itu. Geeru adalah seorang kapitalis diantara semua kapitalis. Dan harus ku katakan, bahkan di negeri yang banyak perut gendut, tdak ada yang menjijikkan seperti perut Geeru. Betapa bahagia dia bersantai-santai di atas kursi malas di rumah.

Geeru adalah seorang kappa yang pandai bergaul.

しかしがらすがいしゃ,硝子会社のしゃちょう,社長のげえる,ゲエルはひと なつ,人懷こいかっぱ,河童だったのに違いありません。

Shikashi garasu kaisha no shachoo no Geeru wa hitonatsu koi kappa datta noni chigai arimasen. (Hal 93)

Di balik semua itu, tida diragukan lagi Geeru, direktur pabrik gelas raksasa itu, adalah seorang yang sangat pandai bergaul.

\section{Tokoh Peppu}

Kappa Peppu adalah seekor Kappa perokok, dimanapun dia berada selalu ditemani sebatang rokok. Peepu juga tidak terlalu suka bicara.

ペップはきんぐち,金口のたばこ, 煙草のけむり, 煙をまずゆうゆう, 悠々と吹 きあ,上げてから、。。)

Peppu wa kinguchi no tabako no hamuri o mazu yuuyuu to fuki, agete kara... (Hal 113)

Peppu juga seekor kappa perokok yang tidak terlalu suka bicara.

しかしペップは何もい,言わずにかなぐち,金口のかんたばこ, 巻煙草にひ,火 をつけていました。)

Shikashi peppu wa nani mo iwazu ni kane guchi no kantabako ni hi o tsukete imashita. (Hal 117)

Tetapi Peppu terlalu sibuk menyalakan rokok dan tidak berbicara sepatah kata pun. Kappa Peppu adalah Kappa yang cuek dan tidak peduli dengan sesama teman Kappa yang lain, maka dari itu Peppu jarang mempunyai teman.

(さいばんかん,裁判官のペっぷ,ペップはあいかわらず、あたら,新しいか んたばこ,巻煙草にひ,火をつけながら、。。)

(Saibankan no peppu wa aikarawazu, atarashii kantabako ni hi o tsukenagara...

(Hal 119)

'Teman? Ah! ..... tapi Peppu selalu seperti serigala yang kesepian.....'

(いかにもつまらなそうにへんじをしました。)

Ika ni mo tsumaranasoo ni henji o shimashita. (Hal 113)

Ia menjawab seolah olah masalah itu bukanlah suatu hal yang serius.

\section{PANDANGAN AKUTAGAWA TERHADAP SISTEM IE}

Akutagawa menceritakan bahwa kelahirannya sesungguhnya tidak diinginkan karena ia lahir saat orang tuanya berusia tertentu, sehingga ia dianggap membawa sial bagi keluarga, lalu dititipkan pada teman ayahnya. Ia merasa kecewa terhadap pandangan sial tersebut, karena hanya memikirkan pihak orang tua, bukan 
kebahagiaan anak. Oleh karena itu, ia berkhayal bila ada dunia yang tidak memiliki pandangan tersebut.

Kekecewaannya terhadap pandangan sial tersebut ia sampaikan melalui tokoh $\mathrm{Aku}$ ketika Aku berdiskusi dengan dr.Chakku. Aku menanyakan apakah pandangan yang diberlakukan di dunia manusia tersebut, diterapkan juga di dunia kappa.

『しかし両新の都合ばかり考えているのはおかしいですからね。どう もあまり手前、勝手ですからね。』

"Shikashi ryooshin no tsugoo bakari kangaete iru no wa okashii desu kara ne. Doumo amari temae, katte desu kara ne.” (hal 75)

Percayalah bahwa ini sangat lucu karena para orangtua hanya mempertimbangkan keaadan mereka sendiri. Tidakah ini menjadi puncak egoisme kalian?

Peristiwa lain yang juga mempertegas kekecewaan Akutagawa terhadap yaitu sewaktu Aku menyaksikan proses melahirkan istri Baggu yang sangat ganjil. Ketika tiba bayi akan keluar, Baggu mendekatkan mulutnya pada jalan lahir bayi lalu dengan suara keras menanyakan apakah calon anaknya benar ingin dilahirkan ke dunia.

\section{『お前はこの世界へ生まれて来るかどうか、よく考えた上で返事をし ろ』}

"Omae wa kono sekai e umarete kuru ka doo ka, yoku kangaeta ue de henji o shiro." (Hal 78)

"Apakah kau benar-benar ingin dilahirkan ke dunia ini ? pikirkan masakmasak sebelum kau jawab”.

Kekecewaan tersebut secara tidak langsung juga menyebabkan Akutagawa menginginkan kehangatan sebuah keluarga yang utuh ketika melihat keluarga lain berkumpul untuk makan bersama dalam sukacita.

Keinginan tersebut ia wujudkan melalui salah satu tokoh Kappa, Tokku yang merindukan kehangatan sebuah keluarga yang dinyatakan pada saat sepulang dari klub super kappa. Tokku menyatakan hal ini pada saat melewati rumah yang jendelanya terbuka. Di dalamnya duduk sepasang suami istri dan tiga anak kappa yang sedang makan malam.

「ぼく,僕はちょうじんてきへんあいいえ,超人的変愛家だとおも,思ってい らがめ、ああいうかてい, 家庭のようこ, 容子をみ, 見ると、やはりららや,羡 ましさをかん,感じるんだよ」「しかしそれはどうかんが,考えてもむじゅ ん,矛盾しているとはおも,思わないかね?」けれどもとっく,トックはつき あ,月明かりのした,下にじっとうで,腕をく,組んだまま、あのちい,小さい まど,空の向うを、—へいわ,平和なごびき,五匹のかっぱ,河童たちのばん さん,晚餐のテーブルを見守っていました。それからしばらくしてこうこ た,答えました。「あすこにあるたまごやき,玉子焼はなん,何とい,言っても、 れんあい,恋愛などよりもえいせいてき,衛生的だからね」

"Boku wa choojinteki henaika da to omotte iraganu, aa iu katei no yooko o miru to, yahari urayamashisa o kanjirun da yo." "Shikashi sore wa doo kangaete mo, 
Dyah Ekawati Eriolita dan Sri Oemiati, Pandangan Dunia Akutagawa dalam Kappa

mujun shite iru to wa omowanai ka ne." Keredomo Tokku wa tsukiakari no shita ni jitto ude o kunda mama, ano chiisai mado no mukau o, heiwa na gohiki no kappatachi no bansan no teburu o mimamotte imashita. Sore kara shibaraku shite koo kotaemashita. "Asuko ni aru tamagoyaki wa nan to itte mo, renai nado yori mo eiseteki da kara ne.” (hal 81)

'Lihatlah aku! Inilah aku yang berpikir bahwa diriku adalah seorang dan pemuja super kappa , namun ketika aku menyaksikan pemandangan keluarga seperti ini, berakhir dengan kecemburuan. 'Ya namun lihatlah ini, aku tidak melihat bagaimana kau dapat berlenggang menerima bahwa ada sesuatu yang bertentangan di sini.'

Tampaknya Tokku tidak mendengarkan kata-kataku, ia berdiri di bawah cahaya bulan purnama, terdiam dan melipat tangannya sembari menatap tajam dan tenang ke arah meja makan keluarga itu. Setelah beberapa saat, ia menjawab 'baiklah, mungkin ketika kau telah mempertimbangkan semua teman dan sahabat, telur goreng itu akan jauh lebih menyehatkan dan higienis dari pada hubungan cinta yang lain.'

Selain itu, Akutagawa melihat bahwa sistem keluarga yang berlaku pada waktu ia hidup telah memberi beban terhadap para penerus keluarga. Ia menyatakan bahwa sistem ie merupakan sesuatu yang paling tidak masuk akal. Keluarga hanya merupakan suatu kelompok orang yang saling menyiksa dengan keegoisan masing-masing. Pernyataan tersebut muncul karena ia sendiri merasa terbebani ketika harus menanggung hidup adik ayah angkat dan keluarga kakaknya saat kakak iparnya bunuh diri. Keinginan untuk menentang sistem tersebut ia sampaikan melalui salah satu tokoh kappa, Tokku.

トックはよく河童の生活だの河童の芸術だのの話をしました。トック の信ずるところに寄れば、当り前の河童の生活ぐらい、莫迦げているもの はありません。親子夫婦兄弟などと言うのはことごとく互いに苦しめ合う ことを唯一の楽しみにして暮らしているのです。

Tokku wa yoku kappa no seikatsu da no kappa no geijutsu da no no hanashi o shimashita. Tokku no shinzuru tokoro ni yoreba, atarimae no kappa no seikatsu gurai, bakagete iru mono wa arimasen. Oyako fuufu kyoodai nado to iu no wa kotogotoku tagai ni kurushimeau koto o yuiitsu no tanoshimi ni shite kurashite iru no desu. (Hal 79)

Tokku selalu berbicara tentang kehidupan dan seni kappa. Dasar keyakinannya adalah bahwa tidak ada sesuatupun di dunia ini yang benar-benar absurd seperti kehidupan kappa di jalanan. Menurutnya, para orang tua dan anak-anak, suami dan istri, kakak dan adik semuanya hanya melewatkan hari-harinya sesuka hati mereka, sehingga membuat hidup menjadi memberatkan satu sama lain.

Pandangan Akutagawa yang menentang sistem ie tersebut, dikuatkan oleh sebuah peristiwa dalam Kappa, yakni ketika tokoh Aku sedang berkunjung ke rumah

Tokku.

トックはある時空の外を指さし「見え」あの莫迦げさ加減を!」と吐き出 すように言ました。空の外の往来にはまだ年の若い河童が一匹、両親らし い、河童を初め、七、八匹の雌雄の河童を頸のまわりへぶら下げながら、 
息も絶え絶えに歩いていました。しかし、僕は年の若い河童の犠牲的精神 に感心しましたから、反ってその健気さを褒め立てました。

Tokku wa aru toki mado no soto o yubisashi "mie! ano bakagesa kagen o!" to hakidasu yoo ni iimashita. Mado no soto no oorai ni wa mada toshi no wakai kappa ga ippiki, ryooshin rashii, kappa o hajime, shichi, happiki no shiyuu no kappa o kubi no mawari e burasagenagara, iki mo taetae ni aruite imashita. Shikashi, boku wa toshi no wakai kappa no giseiteki seishin ni kanshin shimashita kara, kaette sono kenagesa o hometatemashita. (Hal 79)

Suatu hari ,ia menunjuk melalui jendela dan memuntahkan kata-kata nya, "lihatlah disana!, pernahkah kau lihat suatu hal yang demikian bodoh?" aku melihat keluar jendela, tampak di sana kappa yang masih sangat muda berjalan terhuyung-huyung dan hampir kehabisan napas karena mengendong tujuh atau delapan kappa termasuk dua kappa yang agaknya ibu dan bapaknya. Namun masih ada hal lain yang membuatku sangat tersentuh dari pemandangan tadi, semangat pengorbanan diri kappa muda itu yang menurutku sangat mengaggumkan. Hingga aku menemukan kata-kata yang baik untuk usahausahanya yang patut dipuji namun tokku tidak memahaminya.

Kebalikan dari tokoh Aku yang memuji semangat pengorbanan kappa muda tersebut, Tokku menganggap semua itu sebagai suatu kebodohan yang sia-sia. Kebodohan yang harus ditanggung oleh seorang laki-laki berstatus kepala keluarga, karena harus bertanggungjawab terhadap semua hal yang berkaitan dengan keluarganya.

Akutagawa Ryuunosuke mengungkapkan dua poin penting dalam Kappa tentang kekecewaan serta kritiknya terhadap konsep ie. Pertama, hak-hak anak sebagai manusia yang tidak diperhatikan. Kedua, keterikatan serta tanggung jawab penuh yang harus didedikasikan oleh kepala keluarga secara total dalam kesinambungan suatu keluarga seolah-olah mengaburkan eksistensi manusia sebagai individu.

\section{PANDANGAN AKUTAGAWA TERHADAP AGAMA}

Latar sosial dan budaya pada zaman Taishoo mengungkapkan bahwa orang-orang Jepang kurang serius memikirkan kehidupan spiritual. Akutagawa menggambarkan latar tersebut melalui suasana kehidupan beragama di negeri Kappa. Negeri Kappa memiliki beberapa agama, tetapi agama terbesar adalah agama modern yang mengagungkan makanan dan seks atau yang sering disebut dengan aliran "pemuja kehidupan".

『生活教』という訳語は当たっていないかもしれません。この原語は quemoochaです。Chaは英吉利語のism と言う意味に当たるでしょう。 quemooの原形qemmalの訳は単に『生きる』というよりも『飯を食べたり、 酒を飲んだり、交合を行ったり』する意味です。

'Seikatsukyoo' to iu yakugo wa atatte inai kamo shiremasen. Kono gengo wa quemoocha. Cha wa igirisugo no ism to iu yori imi ni ataru deshoo. Quemoo no genkei qemmal no wake wa tan ni 'ikiru' to iu yori mo 'meshi o tabetari, sake o nondari, kookoo o okonattari' suru imi desu. (Hal 121) 
Dyah Ekawati Eriolita dan Sri Oemiati, Pandangan Dunia Akutagawa dalam Kappa

Tapi yang paling penting harus aku katakan bahwa pada umumnya mereka menjadi kaum modernis. Yang juga menjalankan viverisme (pemujaan hidup) (viverisme hanya terjemahan kasar dari bahasa kappa quemoocha. Cha mirip dengan akhiran isme dalam bahasa Inggris, sedangkan quemal yang berasal dari kata quemoo sedikit mengandung arti konsep sederhana tentang 'hidup' atau lebih tepat makan nasi, minum anggur, dan berhubungan seks).

Akutagawa, seperti yang digambarkan dalam riwayatnya, menyatakan bahwa ia hanya memikirkan keinginan duniawi saja, seperti seks dan makanan. Oleh karena itu, ia, melalui tokoh Aku dan tokoh-tokoh Kappa, menyampaikan pandangannya bahwa agama atau kehidupan spiritual merupakan sesuatu yang tidak harus dipikirkan terlalu serius.

僕は勿論物質主義者ですから，真面目に宗教を考えたことは一度もなかっ たのに違いありません。

Boku wa mochiron busshitsu shugisha desu kara, majime ni shuukyoo o kangaeta koto wa ichido mo nakatta no ni chigai arimasen. (Hal 120-121)

$\mathrm{Aku}$ seorang yang materialis, karena itu tidak perlu lagi dijelaskan bahwa aku pernah berfikir serius masalah agama.

もつともチャックは物質主義者ですから、死後の生命などを信じていませ ん。現にその話をした時にも悪意のある微笑を浮べながら、『やはり霊魂 と言うものも物質的存在と見えますね』などと註釈めいたことをつけ加え ていました。

Motto mo Chakku wa busshitsu shugisha desu kara, shigo no seimei nado o shinjite imasen. Gen ni sono hanashi o shita toki ni mo akui no aru bishoo o ukabenagara, "yahari reikon to iu mono mo busshitsuteki sonzai to miemasu ne" nado to chuushaku meita koto o tsukekuwaete imashita. (hal 129)

Tentu saja, sebagai seorang yang materialis, chakku tidak percaya begitu saja dengan hal semacam itu, bahkan ketika ia sedang bercerita, ia menambahkan dengan senyum mengejek di wajahnya. "bagaimanapun, sepertinya jiwa juga benar-benar memiliki eksistensi material, bukankah demikian?"

『。。○ラップさん、あなたはこのかたに我々の聖書くを御覧に入れまし たか?』『いえ。。。実はわたし白身もほとんど読んだことはないので す』ラップは頭の皿を择きながら、正直にこう返事をしました。

“...Rappu san, anata wa kono kata ni wareware no seikaku o goran ni iremashita ka?" "Ie...jitsu wa watashi shiromi mo hotondo yonda koto wa nai no desu" Rappu wa atama no sara o kakinagara, shoojiki ni koo henji o shimashita. (hal 126)

Rappu, apakah kau pernah memperlihatkan pada tuan ini kitab-kitab suci kita? Belum, sejujurnya saya sendiri belum pernah membaca kitab-kitab itu.

Rappu menggaruk garuk cawan yang ada di atas kepalanya, ia mengakui hal ini.

Tokku adalah salah satu contoh Kappa yang tidak mempercayai agama.

詩人のトックは不幸にも僕のように無神論者です。僕は河童ではありませ んから、生活教を知らなかったのも無理はありません。けれども河童の国 に生まれたトックは勿論『生命の樹』を知っていたはずです。僕はこの教 
えに従わなかったトックの最後を燐れみましたから、長老の言葉を遮るよ うにトックのことを話しました。『ああ、あの気の毒な詩人ですね』 長老は僕の話を聞き、深い息を洩らしました。『我々の運命を定める者は 信仰と境遇とだけです。』もつともあなたがたはそのほかに遺伝を教えな さるでしょう。トックさんは不幸にも信仰をお持ちにならなかったのです。 Shijin no Tokku wa fukoo ni mo boku no yoo ni mushinronsha desu. Boku wa kappa de wa arimasen kara, seikatsukyoo o shiranakatta no mo muri wa arimasen. Keredomo kappa ni kuni ni umareta Tokku wa "Seimei no ki" o shitte ita hazu desu. Boku wa kono oshie ni shitagawanakatta Tokku no saigo o rinre mimashita kara, chooroo no kotoba o saegiru yoo ni Tokku no koto o hanashimashita. "Aa, ano ki no doku na shijin desu ne". Chooroo wa boku no hanashi o kiki, fukai iki o morashimashita. "Wareware no unmei o sadameru mono wa shinkoo to kyooguu to dake desu." Mottomo anatagata wa sono hoka ni iden o oshienasaru deshoo. Tokku san wa fukoo ni mo shinkoo o omochi ni naranakatta no desu. (Hal 127)

Tokku seperti juga aku, bukanlah seorang yang percaya. Dalam hal ini bukanlah seekor kappa, ini wajar dan dapat dimaklumi jika aku tidak tahu sama sekali tentang viverisme. Tetapi tokku, yang dilahirkan di negeri kappa seharus nya ia tahu tentang "pohon kehidupan". Aku dibuat sedih dengan kematian tokku yang tidak menerima ajaran agama ini. Lalu aku mengutarakan mesalah tokku dengan memotong kalimat orang tua itu yang mengalir deras. "ah penyair yanga malang itu, maksudmu ?"

Mendengar penjelasanku, orang tua itu menarik napas panjang; "nasib kami ditentukan oleh tiga hal: keyakinan, lingkungan dan kesempatan. Tentu saja, kalian manusia menambahkanya dengan keturunan dalam ketiga aspek ini sehingga menjadi empat faktor. Malangnya, tokku yang malang itu tidak memiliki keyakinan."

Tokoh-tokoh dalam Kappa bahkan merasa bahwa materi yang memberi ketenangan, bukan kehidupan spiritual.

物質的欲望を減ずることは必ず下平和を齎さない。我々は平和を得る ためには精神的欲望も減じなければならぬ。

Busshitsuteki yokuboo o gen zuru koto wa kanarazu shita heiwa o mottarasanai. Wareware wa heiwa o eru tame ni wa seishinteki yokuboo mo genjinakereba naranu. (Hal 109)

'Untuk mengurangi nafsu kebendaan tidaklah selalu membawa ketentraman pikiran'.

'Untuk memperoleh ketenangan, kita juga perlu mengurangi kebutuhan spiritual'.

Meski demikian, Akutagawa masih peduli terhadap kehidupan sesudah kematian. Ia merasa bahwa ia akan memperoleh kedamaian ketika ia meninggal, tetapi ia juga meragukannya, maka ia sempat ragu untuk melakukan bunuh diri. ia menceritakan kepedulian serta keraguannya akan dunia kematian melalui salah satu tokoh Kappa, Maggu.

$$
\text { マッグだけはトックの死骸を眺めたまま、ぼんやり何か考えていま }
$$

す。僕はマッグの肩を吅き、『何を考えているのです?』と尋ねました。 『河童の生活というものをね』『河童の生活がどうなるのです?』『我々 
Dyah Ekawati Eriolita dan Sri Oemiati, Pandangan Dunia Akutagawa dalam Kappa

河童は何といっても、河童の生活を完うするためには、。。。』マッグは 多少羞しそうにこう小声でつけ加えました。『とにかく我々河童以外の何 にものかのカを信ずることですね』

Maggu dake wa Tokku no shigai o nagameta mama, bonyari nani ka kangaete imasu. Boku wa Maggu no kata o tataki, "nani o kangaete iru no desu?" to tazunemashita. "Kappa no seikatsu to iu mono o ne" "Kappa no seikatsu ga doo naru no desu?" "Wareware kappa wa nan to itte mo, kappa no seikatsu o kan'u suru tame ni wa..." Maggu wa tashoo shuushisoo ni koo kogoe de tsukekuwaemashita. Tonikaku wareware kappa igai no nani ni mono ka no chikara o shinzuru koto desu ne" (Hal 121)

Maggu masih saja merenungkan sesuatu dengan mata tertuju pada mayat tokku. Aku menepuk bahu maggu dan bertanya :

"Apa yang sedang kau pikirkan?"

"Oh kehidupan kappa ini"

"Kehidupan kappa?"

"Yah, kau tahu. Ketika semua telah berakhir untuk memenuhi hidupnya, kappa itu."

...Kemudian, ia menambahkan dengan wajah malu-malu dan nada yang lemah.., ia percaya atau yakin pada suatu kekuatan yang benar-benar ada di luar kappa.

\section{PANDANGAN AKUTAGAWA TERHADAP EMANSIPASI WANITA}

Pandangan Akutagawa terhadap perjuangan wanita pada zaman Taishoo memang tidak berkaitan secara langsung dengan riwayat hidupnya. Namun, perubahan sikap wanita terhadap pria maupun masalah politik pada zaman tersebut, membuat Akutagawa kagum, karena sikap tersebut dapat dikatakan tidak lazim. Ia juga berimajinasi bahwa seandainya wanita menyampaikan protes atas pria melalui urusan percintaan, maka para pria pun dapat tunduk pada wanita.

Kekaguman serta imajinasi tersebut, ia tuangkan dalam Kappa melalui sebuah ketetapan tak tertulis yang berlaku di dunia Kappa, yaitu Kappa betina yang mengejar-ngejar Kappa jantan. Kappa betina dapat memaksakan kehendaknya kepada Kappa jantan untuk melakukan hal seperti yang mereka inginkan, terutama urusan bercinta.

一番正直な此の河童は遮二無二雄の河童を追いかけるのです。現に僕は気 違いのように 雌の河童を追いかけている雌の河童を見かけました。いや、 そればかりではありません。

Ichiban shoojiki na mesu no kappa wa saegi ni mu ni osu no kappa o oikakeru no desu. Gen ni boku wa kichigai no yoo ni mesu no kappa o oikakete iru mesu no kappa o mikakemashita. Iya, sore bakari de wa arimasen. (hal 82)

Cara yang paling tidak mengandung nilai seni dan blak-blakan adalah ketika kappa betina membuat aksi yang gila dengan mengejar kappa jantan yang malang. Aku pernah melihat langsung cara pengejaran yang seperti ini. Seekor kappa betina tampak benar-benar gila, penuh semangat ia membabi buta mengejar kappa jantan. 
実際また河童の恋愛は我々人間の恋愛とはよほど趣をことにしています。 雌の河童はこれぞという雄の河童を見つけるが早いか、雄の河童を捉える のにいかなる手段も顧みません。一番正直な此倠の河童は遮二無二雄の河童 を追いかけるのです。現に僕は気違いのように雄の河童を追いかけている 雌の河童を見かけました。いや、そればかりではありません。若い雌の河 童は勿論、その河童の両親や兄弟までいっしょになって追いかけるのです。 雄の河童こそみじめです。

Jissai mata kappa no renai wa wareware ningen no renai to wa yohodo omomuki o koto ni shite imasu. Mesu no kappa wa kore zo to iu osu no kappa o mitsukeru ga hayai ka, osu no kappa o toraeru no ni ikanaru shudan mo kaerimimasen. Ichiban shoojiki na mesu no kappa wa shanimuni osu no kappa o oikakeru no desu. Gen ni boku wa kichigai no yoo ni osu no kappa o oikakete iru mesu no kappa o mikakemashita. Iya, sore bakari de wa arimasen. Wakai mesu no kappa wa mochiron, sono kappa no ryooshin ya kyoodai made issho ni natte oikakeru no desu. Osu no kappa koso mijime desu. (Hal 82)

Pada kenyataannya pola percintaan Kappa dengan percintaan manusia benarbenar berbeda. Begitu Kappa betina menemukan Kappa jantan, maka tanpa mempedulikan hal-hal lain dia akan melakukan cara seperti apapun agar dapat memperoleh kappa jantan tersebut. Kappa betina secara terang-terangan nekat mengejar kappa jantan. Kejadian itu ku anggap sebagai hal yang tidak wajar. Tetapi tidak hanya itu, kappa betina yang masih muda akan ditemani ortu atau saudara kandungnya dalam melakukan pengejaran. Betapa malangnya Kappa jantan.

もつともまた時には雌の河童を一生懸命に追いかける雄の河童もないでは ありません。しかしそれもほんとうのところは追いかけずにはいられない ように雌の河童が仕向けるのです。

Motto mo mata toki ni wa mesu no kappa o isshookenmei ni oikakeru osu no kappa mo nai de wa arimasen. Shikashi sore mo hontoo no tokoro wa oikakezu ni wa irarenai yoo ni mesu no kappa ga shimukeru no desu. (Hal 83)

Memang ada juga Kappa jantan berusaha mengejar kappa betina, tetapi hal tersebut sebenarnya tidak akan terjadi apabila bukan berasal dari rangsangan kappa betinanya.

僕の知っていた雄の河童は誰も皆言い合せたように雌の河童に追いかけら れました。勿論妻子を持っているバッグでもやはり追いかけられたのです。 のみならず二、三度はつかまったのです。

Boku no shitteita osu no kappa wa dare mo mina iiawaseta yoo ni mesu no kappa ni oikakeraremashita. Mochiron saishi o motte iru Baggu de mo yahari oikakerareta no desu. Nomi narazu ni, san do wa tsukamatta no desu. (Hal 84)

Semua kappa jantan yang ku kenal pernah dikejar-kejar Kappa betina. Tentu saja Baggu yang sudah beranak istripun juga diburu. Bahkan pernah tertangkap setidaknya 2-3 kali.

$\mathrm{Aku}$, yang melihat sikap tak lazim kappa betina tersebut, kemudian mendiskusikannya dengan Maggu. Maggu merupakan satu-satunya kappa yang tidak pernah dikejar-kejar. 
Dyah Ekawati Eriolita dan Sri Oemiati, Pandangan Dunia Akutagawa dalam Kappa

「なぜ政府は䧳の河童が雄の河童を追いかけるのをもつと厳重に取り 締らないのです?」

"Naze seifu wa mesu no kappa ga osu no kappa o oikakeru no o motto genjuu ni torishimaranai no desu." (hal 84)

'Mengapa pemerintah tidak melarang tindak kekerasan yang dilakukan kapa betina dengan mengejar-ngejar kappa jantan?'

それは一つには官吏の中に雌の河童の少ないためですよ。

Sore wa hitotsu ni wa kanshi no naka ni mesu no kappa no sukunai tame desu yo. (hal 84)

Salah satu alasannya, yakni hanya sedikit Kappa betina yang duduk di kabinet. Penjelasan Maggu tersebut menggambarkan bahwa wanita telah memiliki keberanian untuk mengadakan protes terhadap pria, karena tidak memenuhi keinginannya untuk berperan dalam dunia politik. Selain itu, bila wanita menunjukkan kekuatannya serta mencari kelemahan pria, maka wanita pun dapat berkuasa sejajar dengan pria, bahkan pemerintah pun tak dapat melawannya.

\section{SIMPULAN}

Berdasarkan hasil analisis data, dapat ditarik simpulan sebagai berikut :

Akutagawa mengungkapkan dalam Kappa beberapa pandangan terhadap sistem keluarga, agama dan emansipasi wanita di Jepang.

Akutagawa Ryuunosuke mengungkapkan dua poin penting dalam Kappa tentang kekecewaan serta kritiknya terhadap konsep ie. Pertama, hak-hak anak sebagai manusia yang tidak diperhatikan. Kedua, keterikatan serta tanggung jawab penuh yang harus didedikasikan oleh kepala keluarga secara total dalam kesinambungan suatu keluarga seolah-olah mengaburkan eksistensi manusia sebagai individu. Hal tersebut diceritakan lewat tokoh Tokku, yang menganggap keluarga sebagai suatu kebodohan yang sia-sia. Kebodohan yang harus ditanggung oleh seorang laki-laki berstatus kepala keluarga, karena harus bertanggungjawab terhadap semua hal yang berkaitan dengan keluarganya.

Akutagawa juga menyatakan pandangannya terhadap sistem agama di dalam Kappa dengan menghubungkan kehidupan beragama pada zaman Taishoo. Pada zaman Taishoo sudah terdapat berbagai aliran agama, di antaranya Shinto dan Konfusianisme. Namun, banyaknya aliran kepercayaan tersebut, justru membuat orang Jepang tidak berpedoman pada satu agama, serta makin membuat mereka memuja keduniawian.

Akutagawa tidak mengkritik emansipasi wanita yang terjadi pada zaman Taishoo. Ia justru menceritakan kekagumannya terhadap wanita Jepang yang 52 memperjuangkan hak dan suaranya dalam kehidupan sosial maupun politik pada zaman itu. Wanita pada zaman itu telah berusaha menyejajarkan dirinya dengan pria, salah satunya dengan duduk di kursi pemerintahan. Wanita juga mulai berani mengutarakan protes akibat perlakuan atas nama gender yang tidak adil dalam kabinet dengan menekan para pria melalui urusan bercinta.

\section{DAFTAR PUSTAKA}


Beongcheon, Yu. 1972. Akutagawa : An Introduction. Detroit. Wayne State University Press.

Damono, Sapardi Djoko. 1984. Sosiologi Sastra Sebuah Pengantar Ringkas. Jakarta : Pusat Pembinaan dan Pengembangan Bahasa.

Dasuki, A -------.. Sedjarah Djepang Djilid II. Bandung : Dep. P.P.K

Faruk, HT.1994. pengantar sosiologi sastra : Dari strukturalisme genetic sampai post modernisme. Jogjakarta : Pustaka pelajar

Mattulada, 1979. Pedang dan Sempoa (suatu analisa cultural "perasaan kepribadian orang Jepang"). Jakarta, Departemen Pendidikan dan Kebudayaan.

Nuriyantoro, Burhan. 1995. Teori Pengkajian Fiksi. Yogyakarta : Gadjah Mada University Press.

Rosidi, Ajip. 1998. Mengenal Sastra dan Sastrawan Jepang. Jakarta : Erlangga.

Sangidu. 2004. Penelitian Sastra : Pendekatan, Teori, Metode, Teknik, dan Kiat. Yogyakarta. Unit Penerbitan Asia Barat FIB-UGM

Shiojiri, S. 1970. Ryuunosuke Akutagawa'S KAPPA. Connecticut. Greenwood Press Publishers

Swingewood, Alan dan Diane Laurenson. 1972. Sociology of Literature. London : Granada..

Ueda, Makoto. 1976. Moderen Japanese Writer and The Nature of Literature. California : Standford University Press.

Wibawarta, Bambang. 2004. Akutagawa Ryuunosuke Terjemahan dan Pembahasan. Jakarta, Kalang.

Situs-situs :

http://www.speaking.japanese.com/bio_akutagawa.html diambil tanggal 15 Febuari 2009 pukul 18.57

www.f.waseda.jp/mjewel/jlit/authors_works/moderenlit/akutagawa_ryunosuke.ht

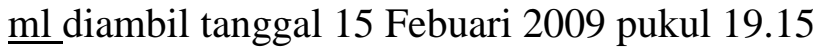

